\title{
Water Resource Management in Dry Zonal Paddy Cultivation in Mahaweli River Basin, Sri Lanka: An Analysis of Spatial and Temporal Climate Change Impacts and Traditional Knowledge
}

\author{
Sisira S. Withanachchi ${ }^{1, *}$, Sören Köpke ${ }^{2}$, Chandana R. Withanachchi ${ }^{3}$, Ruwan Pathiranage ${ }^{4}$ \\ and Angelika Ploeger ${ }^{1}$
}

1 Department of Organic Food Quality and Food Culture, University of Kassel, Nordbahnhofstr. 1a, 37213 Witzenhausen, Germany; E-Mail: a.ploeger@uni-kassel.de

2 Institute for Social Sciences, Technische Universität Braunschweig, Bienroder Weg 97,

D-38106 Braunschweig, Germany; E-Mail: soeren.koepke@tu-braunschweig.de

3 Department of Archaeology and Heritage Management, Rajarata University, Mihintale 50300, Sri Lanka; E-Mail: chandanawithanachchi@gmail.com

4 Eco-collective Research Association, Colombo 00200, Sri Lanka;

E-Mail: pathiranageruwanefc@gmail.com

* Author to whom correspondence should be addressed: E-Mail: sisirawitha@uni-kassel.de;

Tel.: +49-0-5542-98-1722; Fax: +49-0-5542-98-1713.

External Editor: Monica Ionita-Scholz

Received: 28 July 2014; in revised form: 21 October 2014 / Accepted: 30 October 2014 /

Published: 18 November 2014

\begin{abstract}
Lack of attention to spatial and temporal cross-scale dynamics and effects could be understood as one of the lacunas in scholarship on river basin management. Within the water-climate-food-energy nexus, an integrated and inclusive approach that recognizes traditional knowledge about and experiences of climate change and water resource management can provide crucial assistance in confronting problems in megaprojects and multipurpose river basin management projects. The Mahaweli Development Program (MDP), a megaproject and multipurpose river basin management project, is demonstrating substantial failures with regards to the spatial and temporal impacts of climate change and socioeconomic demands for water allocation and distribution for paddy cultivation in the dry zone area, which was one of the driving goals of the project at the initial stage. This interdisciplinary study explores how spatial and temporal climatic changes and uncertainty
\end{abstract}


in weather conditions impact paddy cultivation in dry zonal areas with competing stakeholders' interest in the Mahaweli River Basin. In the framework of embedded design in the mixed methods research approach, qualitative data is the primary source while quantitative analyses are used as supportive data. The key findings from the research analysis are as follows: close and in-depth consideration of spatial and temporal changes in climate systems and paddy farmers' socioeconomic demands altered by seasonal changes are important factors. These factors should be considered in the future modification of water allocation, application of distribution technologies, and decision-making with regards to water resource management in the dry zonal paddy cultivation of Sri Lanka.

Keywords: monsoon climate; trends in precipitation; extended and short-term drought; floods; water availability; seasonal cultivation system (yala and maha); cross-scale dynamics and effects; Mahaweli Development Program (MDP)

\section{Introduction}

Integrated approaches to natural resource management have to consider diverse spatial and temporal scales [1]. River basin management directly and indirectly affects the way socioeconomic needs compete with ecological conditions. Thus, water basins are spatially and temporally entwined with natural scales (such as climate, hydrology, and ecology), socioeconomic scales (such as riparian communities, harvesting seasons, and agricultural fields), and political-administrative scales (such as localities and management zones) [2,3]. Cross-scale dynamics and effects in water resource management are a challenging proposition in the environmental policy-making process. As Termeer et al. [4] illustrate, how to govern and manage multi-scale problems is an open and important question in the policy-making process, where contemporary society interconnects with the complex nexus between nature and humans. Cross-scale dynamics and the effects of climate change ought to be an important consideration in the institutionalization of river basin management, especially regarding water allocation and distribution. Particularly, variations in climate and long-term weather patterns influence spatial and temporal scales in water resource management.

The dry zonal area in Sri Lanka contributes $70 \%$ of national paddy cultivation. As the report on Climate Change Vulnerability in Sri Lanka [5] states, the dry zonal area is highly vulnerable due to a prolonged drought season and diminishing precipitation. Paddy cultivation in dry zonal areas mainly depends on irrigated water. Therefore, paddy cultivation is mainly based on the river basin-oriented complex water management system. Paddy is a water-sensitive crop in every agronomic period. There are three agronomic periods in paddy cultivation: (1) vegetative (germination to panicle initiation), (2) reproductive (panicle initiation (PI) to heading), and (3) grain filling and ripening or maturation [6]. Changes in flow regimes in the mainriver, tributaries, and canals, as well as fluctuation in precipitation, can have an impact on the quantity and quality of paddy harvest.

The Mahaweli River, the longest river in Sri Lanka, flows for $335 \mathrm{~km}$, covering about 16\% of Sri Lanka's land area [7]; it is a key water source in the dry zone area. Based in the Mahaweli River Basin, the Mahaweli Development Program (MDP) was initiated as an empowerment program of paddy 
cultivation and human settlement in accordance with the agricultural system in the dry zonal area. As a second wave of river basin management, the MDP followed the prototype of Tennessee Valley Authority (TVA) (Jeroen Warner et al. [8]). It entails the construction of large-scale dams and establishes an authority-based hydraulic bureaucracy in river basin management to accelerate economic development. However, in the context of the water-climate-food-energy nexus, the MDP is demonstrating substantial failures with regards to the spatial and temporal impacts of climate change and socioeconomic demands for water allocation and distribution for paddy cultivation in dry zone areas.

The aim of this research paper is to examine how spatial and temporal climatic changes and uncertainty in weather conditions impact paddy cultivation in the dry zonal area, taking into account stakeholders' interest in the Mahaweli River Basin and how they compete. The structure of this research paper is as follows: the theoretical framework of cross-scale dynamics and effects will be in the next section. In the following section, the materials and methods of the research study will be evaluated. The fourth section will elaborate the results with a discussion of the findings. The research paper concludes with a brief summary of the main arguments and further research possibilities.

\section{Theoretical Framework: Cross-Scale Inquiries of Water Resource Management}

The scale as understood in this research is based on the definition of Gibson et al. [9], where a scale consists of the spatial, temporal, quantitative, or analytical dimensions that are used to measure and study any phenomenon. Cash et al. [10] advance this definition through a multi-scale understanding of environmental, geophysical, and ecological phenomena. Temporally, biophysical and social phenomena can be observed in a range of timeframes such as seasonal, electoral, budgeting, and development projects. The spatial scales correlate with levels where the socioeconomic and human-nature interaction is processed [10].

Practically, human-environment interactions are entwined across different spatial and temporal scales [10-12]. With special attention to the thematic research area "climate system", the impacts of climate change and uncertainty in weather conditions could alter and transform societal and institutional behaviors $[13,14]$. In particular, formal and informal decisions on agriculture and irrigation, such as cultivating periods, crop rotation, water allocation, and distribution, depend on temporal and spatial climate scales $[15,16]$. Furthermore, the spatial expansion of climatic zones and long-term fluctuations in climate and weather patterns including drought conditions and floods are crucial factors in designing policies of water allocation and distribution. Changes in climate conditions are likely to modify decisions and technology implementation in water resource management. Therefore, analysis of cross-scale dynamics and effects are important in the policy-making process of natural resource management $[1,4,10]$. As for the cross-scale dynamics, the different temporal and spatial scales have different movements and alterations in time frames and levels. Some of these dynamics impact other scales, which are known as cross-scale effects [10,17].

In hydro-social relationships, water is embedded within a physical context and on the other side, within deep sociocultural and political economic contexts $[18,19]$. It is constituted through varied social and material productions of scale. For instance, a naturally flowing river can be regulated through building dams, establishing new human settlements with agricultural projects, or forming canals and industrial projects [19]. The process of demarcating or choosing a scale is neither politically neutral nor entirely 
based on biophysical characteristics. It is a process where different stakeholders are involved in assessment by researching, reviewing, and synthesizing data as well as policy-drafting and policy implementation [20]. Thus, river basins are hydrological units where stakeholders compete and negotiate based on their conflicting interests $[21,22]$. Accordingly, the river basin is not a single hydrological scale, but a multiplex of several biophysical, socioeconomic and political-administrative scales [23]. The dynamics and effects of each scale on other scales are crucial in the policy-making process [3,21,22]. Cash et al. [10] characterized the complex interaction between human-environment systems as a synergy of scales that causes substantial complexity in dynamics. Water allocation and distribution is a pillar of water resource management and is considered a process of managing scarce resources with competitive and contested interests, with demand under pressure from other ecological constraints [15]. Spatial and temporal climatic changes and uncertainty in weather conditions is a decisive factor in water allocation and distribution. In this research study, spatial and temporal climate change and uncertainty in weather conditions are identified as the key biophysical factors in the examination of cross-scale dynamics and effects in water resource management.

\section{Materials and Methods}

Field work was conducted in three divisional secretariats in the Anuradhapura district (Eppawala, Thambuthegama, and Horrowpothana), as well as in Kantale in the Trincomalee district and Dambulla in the Matale district, all within the Mahaweli River Basin area (Figure 1). Though the Horrowpothana research area is not directly located within the Mahaweli irrigated regions, its water resource management is connected with the Mahaweli river basin system and management network. These divisional secretariats are located in the dry zone of Sri Lanka. The mean annual precipitation of the dry zone is less than $1200 \mathrm{~mm}$ [24], average annual evaporation is $1400 \mathrm{~mm}$ and average temperature is about $33{ }^{\circ} \mathrm{C}$ [25]. Sri Lanka is divided into three agroecological climate zones depending on annual precipitation, including dry zone. Other zones are the wet zone (high mean annual precipitation over $2000 \mathrm{~mm}$ ) and the intermediate zone (mean annual precipitation between $2000 \mathrm{~mm}$ and $1200 \mathrm{~mm}$ ), (Figure 1) [24].

The research followed the embedded design in the mixed methods research approach [26,27], as the study deals with a pragmatic and complex problem that entails both social and ecological factors. In the framework of embedded design, qualitative data was the primary source while quantitative analyses were used as supportive data. Field research from May 2012 to April 2014, semi-structured interviews, focus group discussions, and community observation were used as qualitative data-gathering methods, including primary and secondary data. We conducted interviews with members of the local communities, as well as experts and officers who held administrative and technical positions. Some of the local people interviewed are engaged in other social and economic activities. Some of them are working as community leaders or village representatives of farmers' associations (political party-oriented or not). In terms of occupation, some are working in multiple sectors (farming and fishing, or farming and livestock). In the two phases of field research, we interviewed local people $(\mathrm{N}=45)$. The interviews were conducted according to a group discussions model, with semi-structured questions. Snowball sampling was used to select the interviewees. 
Figure 1. Climate zones and irrigated regions (irrigation systems/zones) in the Mahaweli Development Program, and areas where field research was conducted (authors' illustration).

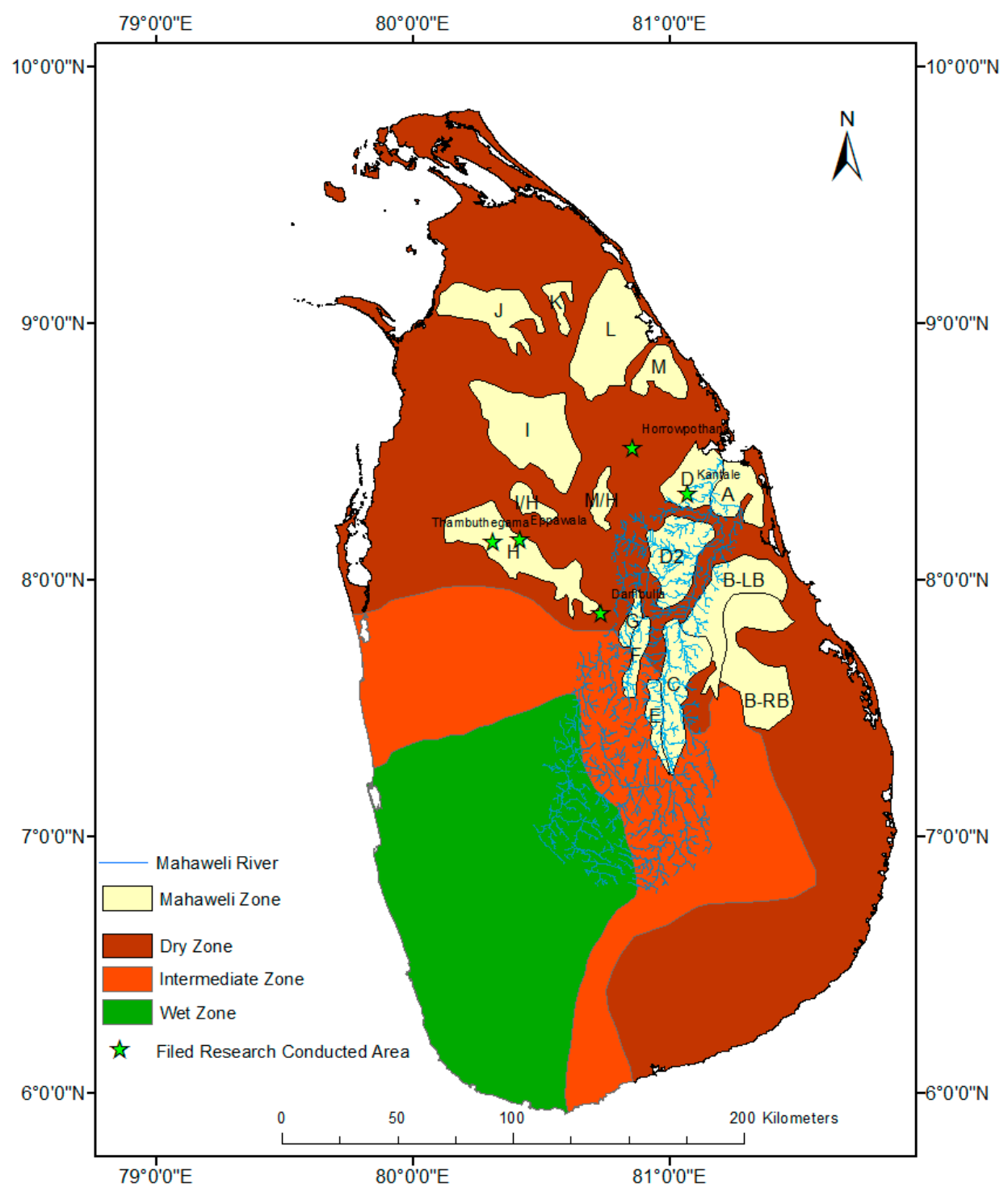

We also considered the oral history factor [28] to record the generational changes of agricultural systems in the dry zone area and the climate changes experienced in agriculture. Furthermore, experts and officials were interviewed $(\mathrm{N}=35)$, from several governmental institutes, academic foundations, non-government organizations, political parties, the media, and universities (Table 1). In addition, legal documents and policy papers were other sources of information on relevant policy implementation and dynamics. The gathered data were analyzed by applying the interpretative approach within the embedded design of mixed methods research. The climate change impact and weather conditions in the spatial changes were analyzed based on recent climate research studies and databases. 
Table 1. The list of institutional interviews (2012-2014).

\begin{tabular}{|c|c|}
\hline Category of Stakeholder & Institution ${ }^{1}$ \\
\hline Agricultural administrative sector & $\begin{array}{c}\text { - Mahaweli Authority, divisional branches } \\
-\quad \text { Divisional Agrarian Office } \\
-\quad \text { Divisional Irrigational Office } \\
\text { - } \quad \text { Water Project Field Office } \\
\text { - Central Environmental Authority regional office } \\
\text { - Paddy Board regional office }\end{array}$ \\
\hline $\begin{array}{c}\text { Non-agricultural administrative } \\
\text { office }\end{array}$ & $\begin{array}{c}\text { - Divisional Health Office } \\
-\quad \text { Divisional Administrative Offices } \\
-\quad \text { Public Health Inspector Office } \\
\text { - Local council administrative and technical officers } \\
\text { (secretaries, maintenance, development and welfare officers) } \\
\text { - } \quad \text { Village Officers (Grama Niladari) }\end{array}$ \\
\hline Political representation & $\begin{array}{c}\text { - Provincial council representatives } \\
-\quad \text { Local council members } \\
-\quad \text { Political party activists } \\
\text { - } \quad \text { Village-based representatives }\end{array}$ \\
\hline $\begin{array}{l}\text { Academics or other regional } \\
\text { experts }\end{array}$ & $\begin{array}{c}\text { - } \quad \text { Researchers } \\
\text { - } \quad \text { Village-based school teachers } \\
\text { - } \quad \text { Regional media reporters } \\
\end{array}$ \\
\hline Non-government organization & $\begin{array}{c}-\quad \text { World Vision } \\
\text { - } \quad \text { RECDO (Rural Economic and Community Development } \\
\text { Organization) }\end{array}$ \\
\hline $\begin{array}{c}\text { Community based group or } \\
\text { individuals }\end{array}$ & $\begin{array}{c}\text { - } \quad \text { Religious leaders or representatives at village level } \\
\qquad \quad \text { Farmers } \\
-\quad \text { Fishermen } \\
-\quad \text { Livestock sector } \\
-\quad \text { Retail sellers }\end{array}$ \\
\hline
\end{tabular}

1. The table indicates only the institutional or group names due to the ethical concern of the research study.

\section{Results and Discussion}

Spatial and temporal climate scale statuses are crucial factors in river basin management [29-31]. The decadal, annual, and seasonal variations and spatial dynamics in climate conditions are vital factors to be considered in the policy-making process of multi-purpose river basin management [11,30,31]. In the Mahaweli River Basin, spatial and temporal climatic changes influence the reconfiguration of hydro-social and hydro-political relationships in water resource management. Particularly, the flow regimes of the Mahaweli River are affected by spatial and temporal climate variation, which leads to asymmetrical opportunities in access to water resources - some social groups or stakeholders are empowered while others are disempowered or excluded. In this results and discussion section, the impact of spatial and temporal climate change and uncertainty in weather conditions are analyzed alongside socioeconomic demands and administrative and management concerns in paddy cultivation (Figure 2). 
Figure 2. Combination of spatial and temporal scales in Mahaweli Basin water management.

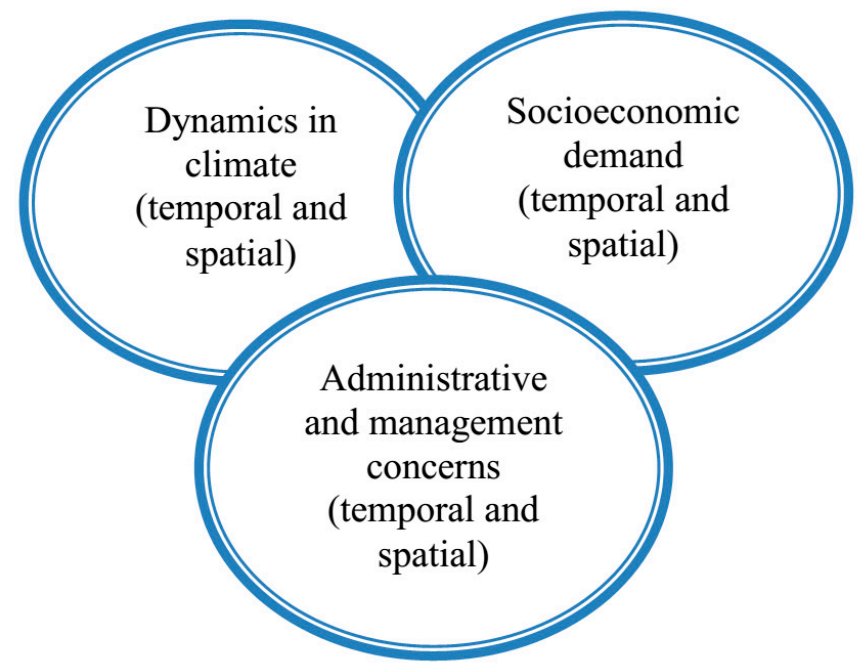

\subsection{Spatial and Temporal Climate Change and Uncertainty in Weather Systems}

\subsubsection{Climate Scientific Observations and Predictions}

Sri Lanka is mainly exposed to the Southwest monsoon (June to October), and the Northeast monsoon (December to March). Also, orographic precipitation is activated in the period from March to April and October to November because the island is located in the Inter-tropical Convergence Zone (ITCZ) [32,33]. The Mahaweli River flows from the wet and intermediate zones to the dry zone, which covers about 10,300 $\mathrm{km}^{2}$ in the basin area [7]. The downstream area of the Mahaweli River Basin is expanding paddy cultivation. De Silva et al. [24] identify the main agro-ecological zones for paddy growing located in the Anuradhapura and Polonnaruwa districts, which mainly spread into the Mahaweli River Basin area.

According to Lasantha Manawadu and Nelun Fernando's [34] analysis, rainfall considerably declined in the wet zone and the intermediate zone. They demarcated the climate zones based on the isohyets of rainfall on average in the wet, intermediate, and dry zones. The $2200 \mathrm{~mm}$ isohyet is the line between the wet and intermediate zones and the $2000 \mathrm{~mm}$ isohyet is the contour between the intermediate and dry zones [34]. Though, the mean annual precipitation of the dry zone is less than $1200 \mathrm{~mm}$ [24], the field data demonstrates that the monthly precipitation in some areas of the dry zone could diminish to less than $50 \mathrm{~mm}$. According to Manawadu and Fernando's [34] analysis, the geological area in the $2200 \mathrm{~mm}$ isohyet diminished from $41,582.75 \mathrm{~km}^{2}$ to $37,000 \mathrm{~km}^{2}$ between 1963 and 2002 . The geological area in the $2000 \mathrm{~mm}$ isohyet has been diminished by about $9,723 \mathrm{~km}^{2}$ between 1960 and 2000. In contrast, the dry zone has expanded from $25,323.84 \mathrm{~km}^{2}$ to $57,227.43 \mathrm{~km}^{2}$ (Figure 3). This is an approximate doubling of the dry zone area over the last 40 years [34]. De Silva et al. [24] also analyzed significant spatial changes in climate zones as a consequence of climate change. Accordingly, the spatial expansion of the dry zone would impact water allocation and distribution, and paddy cultivation. In contrast, Muththuwatta and Liyanage [35] predict that the intermediate zone would enlarge by $21.8 \%$ and the dry zone would dwindle by $8.1 \%$ by 2050 when compared to present land areas. They calculate the shifting boundaries by observing precipitation patterns from 1970 . However, the important dynamic of these analyses is that 
climate change would alter the climate zones and increase the potential for drought conditions in the dry zone area.

Figure 3. Isohyet changes in climate zone in Sri Lanka from 1962 to 2002. (The map is illustrated based on the analysis of the Manawadu and Fernando research study [34].)

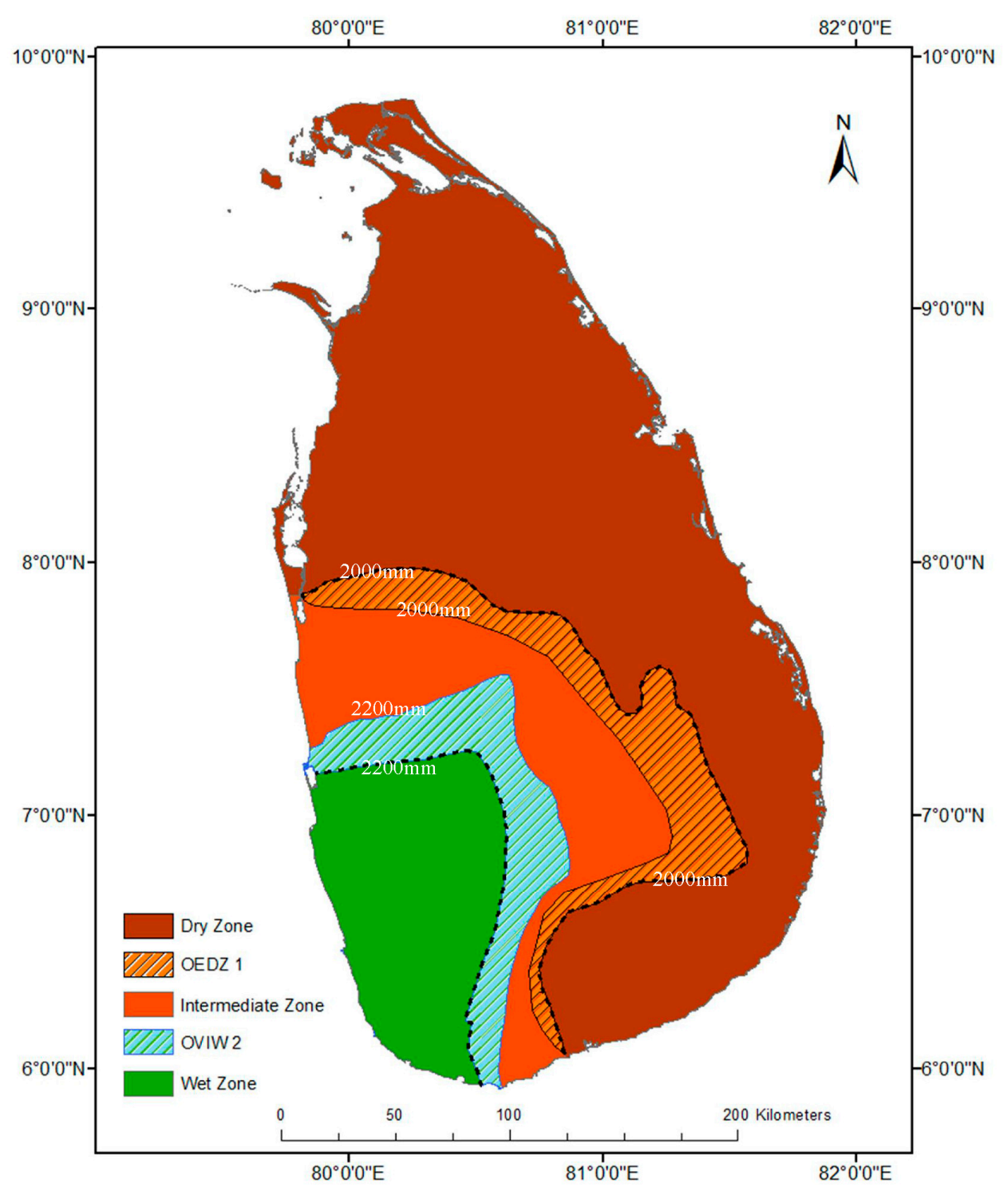

OEDZ: Observed expansion area of dry zone (fluctuating); OVIW: Observed vulnerable area of intermediate zone and wet zone (fluctuating).

Precipitation has been dramatically altered due to climate change and the uncertainty of weather patterns in the Mahaweli River Basin. The upstream areas are experiencing high fluctuations of precipitation with further declining rainfall. W.W.A Shantha and J.M.S.B Jayasundara [36] predict a $16.6 \%$ reduction in rainfall in the upper catchment areas of the Mahaweli River Basin in the highlands by 2025 . Precipitation in the upper catchment area is experiencing an approximate $39.12 \%$ decline, which is a considerable reduction over the last 100 years [36]. Based on these estimations, the seasonal flow regime may drastically reduce as a general average. Moreover, Manfred Domroes and Dirk Schaefer [31] observe substantial reduction of annual average precipitation in Anuradhapura within the 
periods of 1895 to 1996 and 1960 to 1996 during their research study, which calculates the trends of temperature and rainfall changes in Sri Lanka. Eriyagama et al. [37] estimate that mean air temperatures may increase by about $0.9{ }^{\circ} \mathrm{C}$ to $4{ }^{\circ} \mathrm{C}$ by 2100 and the average rainfall will decrease. According to the IPCC report [38], the air temperature in Sri Lanka increased $0.016{ }^{\circ} \mathrm{C}$ per year. Within the period of 1990 to 2011 , the minimum air temperature has increased by about $0.015^{\circ} \mathrm{C} \cdot \mathrm{y}^{-1}$ [39]. This change in the air temperature reflects considerable changes in the climate conditions of Sri Lanka's dry zone.

According to the IPCC analysis [40], unpredictable weather changes can be expected due to abrupt climate change and climate variability. The El Niño southern oscillation (ENSO), which is identified as seasonal climate variability, is observed as seasonal climate variability in Sri Lanka. El Niño has a considerable impact on Sri Lankan precipitation and temperatures. The rainfall in the period from October to December intensifies, and further reduces in the period from January to March and July to August. Also, in the western hill slopes, including the upper catchment area in the basin, the intensification of rainfall in the period from October to December impacts stream flow, which causes inundation in downstream areas $[41,42]$. Furthermore, low pressure disturbances in the southwest Bay of Bengal and Southeast Arabian Sea generate tropical cyclones [43]. These tropical cyclones have a substantial impact on the Sri Lankan weather system due to heavy rainfall. For example, the dry zone areas are prone to flooding and tropical cyclones due to topographical conditions and mismanagement of flood control and irrigation systems (this will be discussed further in Section 4.4).

\subsubsection{Traditional Knowledge in Climate Change and Uncertainty in Weather Systems}

Local and traditional knowledge about climate and weather systems is often disregarded in national policy drafting or scientific analyses in climate studies. This tendency can be repeatedly observed in policy implementation and methodological applications in water resource management. Local people's experiences of climate history and baseline data are decisive and convenient sources in climate studies and may aid in the development of sustainable climate change mitigation and adaptation strategies [44,45]. Their long-term experience of adapting to climate change in the field and familiarity with traditional technologies, due to their livelihood, could allow them to successfully address the declining harvest and water allocation and distribution issues [46,47].

Field interviews with locals reveal their experiences of climate change and its impact on paddy cultivation and their livelihood, as well as traditional knowledge about water allocation and distribution. Table 2 codes the main responses in interviews and focus group discussions at the research locations. All interview data illustrate the presence of extended drought conditions throughout the last 20 years. Long-term droughts occurred with a high frequency in the annual period of May to November during the last 20 years, according to the interviewees' experience. Some interviewees recalled climate and weather pattern fluctuations over a period of 40 years, thus disclosing more empiric evidence of drought conditions and changes in usual seasonal cultivation systems. Particularly, farmers are recurrently impacted by short-term drought conditions, which may continue for a few weeks or less than one month. According to the interviewed farmers, short-term droughts could produce serious threats to agriculture and household water supply with unexpected water shortages. Short-term droughts may occur even during the October to February period, when people expect the annual Northeast monsoon, or in the inter-monsoon season in March. In particular, farmers' experiences demonstrate the recurrence of severe 
drought conditions during yala and maha seasons over the last 40 years. The official reports confirm the occurrence of drought conditions as well as floods, both seriously affecting the livelihoods of local people $[5,48-50]$.

Table 2. The main responses (coded) in interviews and focus group discussions.

\begin{tabular}{|c|c|c|c|c|c|c|}
\hline \multirow[b]{2}{*}{$\begin{array}{c}\text { Research } \\
\text { Location }^{1}\end{array}$} & \multicolumn{6}{|c|}{ Responses (Coded) } \\
\hline & $\begin{array}{c}\text { Extended } \\
\text { Long- and } \\
\text { Short-Term } \\
\text { Drought }\end{array}$ & $\begin{array}{l}\text { Unexpected } \\
\text { Flooding }\end{array}$ & $\begin{array}{c}\text { Changing of } \\
\text { Usual } \\
\text { Seasonal } \\
\text { Cultivation } \\
\text { System } \\
\end{array}$ & $\begin{array}{c}\text { Lack of } \\
\text { Water } \\
\text { Supply for } \\
\text { Agriculture }\end{array}$ & $\begin{array}{c}\text { Losses of } \\
\text { Paddy } \\
\text { Harvest }\end{array}$ & $\begin{array}{c}\text { Disregarding } \\
\text { of Traditional } \\
\text { Knowledge in } \\
\text { Water } \\
\text { Management }\end{array}$ \\
\hline Eppawala & $\sqrt{ }$ & $\sqrt{ }$ & $\sqrt{ }$ & $\sqrt{ }$ & $\sqrt{ }$ & $\sqrt{ }$ \\
\hline Thambuthegama & $\sqrt{ }$ & $\sqrt{ }$ & $\sqrt{ }$ & $\sqrt{ }$ & $\sqrt{ }$ & $\sqrt{ }$ \\
\hline Horrowpothana & $\sqrt{ }$ & $\sqrt{ }$ & $\sqrt{ }$ & $\sqrt{ }$ & $\sqrt{ }$ & $\sqrt{ }$ \\
\hline Kantale & $\sqrt{ }$ & - & $\sqrt{ }$ & $\sqrt{ }$ & $\sqrt{ }$ & $\sqrt{ }$ \\
\hline Dambulla & $\sqrt{ }$ & - & $\sqrt{ }$ & $\sqrt{ }$ & $\sqrt{ }$ & $\sqrt{ }$ \\
\hline
\end{tabular}

Local people encountered unexpected floods in the inter-monsoon period in March or April in Horrowpothana and Eppawala. Also, changes of rainfall during the Northeast monsoon (October to February) cause severe floods in these regions. According to the farmers' experiences, they used to have seven days of rain in February, called "hathda wähi". However, they observed disorder of this rainfall, either long-term rainfall or drought conditions in February. After this rainfall, most farmers usually aim to start the cultivation period knows as yala in the period of March-April. Therefore, they pay attention to changes in the weather system of the dry zone area because of economic relevance to their families. An important finding of reviewing the local-based traditional knowledge about climate and weather systems is that local people are aware of short-term weather changes and long-term changes in the climate system of the Mahaweli River Basin areas. This knowledge is either used to adapt to long-term climate change or communicated to village-level or regional officers in the Mahaweli Authority.

\subsection{Water-Climate-Energy-Food Nexus in Competing Interests of Scale (Re) Configuration}

The Master Plan for the MDP was assessed in 1965-1968 by the United Nations Development Program (UNDP), the Food and Agriculture Organization (FAO) team, and Sri Lankan engineers [50,51]. The program was implemented in 1970 and then restarted in 1977 under the new government. Hydropower generation and agricultural development could be observed as the main political objectives that motivated the MDP. Water allocation and distribution are based on the competitive interests of stakeholders in the MDP. The demand for water resources is shared among macro and micro hydro-electrical plants, vegetable farmers upstream (mainly in the highland of Sri Lanka), paddy farmers downstream, and industries. Through an analysis of the temporal locus of the development paradigm, it could be observed that the locus and focus of the MDP have been changing. As a result of state-oriented development programs after independence in 1947, large-scale and multi-purpose water resource management programs were politically manifested. The state-led development before the 1980s was 
mainly motivated by promoting welfare programs and land reform for peasant farmers, allocating lands for agriculture in semi-arid dry zone areas with relatively low population density, and promoting paddy cultivation in the national economy [52,53].

To promote paddy cultivation in the national economy, new paddy fields were constructed in Mahaweli Basin irrigation regions and then were distributed among new settlers. The downstream area of the Mahaweli River Basin has been demarcated into 13 irrigation regions (Figure 1). Each region has been divided into sub-regions from 1000 hectares to 1500 hectares in land area [54]. Furthermore, these sub-regions have been partitioned into hamlets (village units) of 150 families [55]. The aim of the divisions is a manageable irrigation region and functional human settlement system [54,55]. According to new information in 2012, there are 365,000 cultivated hectares in the Mahaweli River Basin area, including 10,049 $\mathrm{km}$ of canal networks [48]. Currently, approximately 2.8 million people live in the Mahaweli River basin, which is about $15 \%$ of the population of Sri Lanka [7]. There are about 166,269 households in the Mahaweli settlement areas [50]. Most settlers migrated from the central parts or western hill slopes of Sri Lanka as landless peasants [56]. They settled under the government program in the Mahaweli irrigated regions (Mahaweli Irrigation Systems/Zones) from A to M (Figure 1). Each household was permitted 1 hectare of irrigated lowland for paddy cultivation and 0.2 hectares of rain-fed highland farm steading [56]. The spatial responsibilities of the Mahaweli Authority extend beyond the physical context of the Mahaweli River Basin. Chiefly, the Udawala project in the Walawe River Basin in southern Sri Lanka and some irrigational regions including H, I, L, and M are located beyond the physical context of the Mahaweli River Basin (Figure 1). Furthermore, the irrigation regions $\mathrm{M}$ and $\mathrm{M} / \mathrm{H}$ are located in the Yan Oya basin. These sub-river basins are connected by water diversion from the Mahaweli River. As discussed, water diversion between sub-river basins is another purpose of the MDP.

In contrast, neoliberal political transformation was the driving force of state policies after the 1980s. Within this context, the government acts as a facilitator to construct infrastructure facilities for the private sector in the context of a market economy [53]. This created vital changes in the focus of the MDP by facilitating electricity generation for the Free Trade Zones. From the 1980s onwards, the priority of the MDP shifted to establishing hydropower plants by constructing large dams upstream and in the middle reach of the Mahaweli River [52,57]. Large dam constructions are the expression of a modernization path following a Western technologic-economic rationality. Large, multi-purpose dams are the center of the hegemonic hydraulic paradigm [58], and their planning and implementation have often disregarded concerns for social and environmental sustainability. In the case of the MDP, major foreign investments have been allocated to constructing water reservoirs as the basis of hydropower generation, such as the Kotmale, Victoria Randenigala, Rantembe, Ulhitiya/Ratkinda Madu Oya Maduru Oya, Bowetenna, Udawalawe, Ukuwela, and Polgolla hydropower plants. Meanwhile, the MDP is being expanded to new spatial areas beyond the physical context of the Mahaweli River Basin, to include such ventures as the Moragahakanda and Kaluganga Rivers Development Projects, the Rambaken Oya Development Project, and the Kiwul Oya Reservoir Development Projects [50]. Under the Moragahakanda-Kaluganga Project in 2007, the government expects to enhance hydropower generation as well as drinking water purposes and cropping intensity in the Mahaweli River Basin settlement areas [50]. In $2005,30 \%$ of national hydropower production was from the hydropower plants within the Mahaweli system [36].By contrast, 49\% of national hydropower was generated under the MDP in 2011. The total 
power generation to the national grid from the Mahaweli system is 1975 Gigawatt hours (GWh), which is $49 \%$ of the total hydro power in Sri Lanka [50].

The gradual socioeconomic transformation from an agriculture-oriented society into a more industrial-oriented society [37] may place high demands on water resources in the MDP. The statistical analysis of the sectoral water withdrawal in Sri Lanka demonstrates the increase of industrial water use and domestic water use, and the gradual decrease of agricultural water demand. As Figure 4 shows, the irrigational usage of water has gradually declined. It is estimated that irrigational water usage in 2025 will be between $70 \%$ and $75 \%$. However, other competing sectoral water demands challenge the demand for water in paddy cultivation. According to this trend, water usage for domestic purposes and industries are expected to gradually increase. FAO-AQUASTAT data on renewable internal freshwater resources per capita per year (actual) in Sri Lanka indicates $2482 \mathrm{~m}^{3}$ in 2014 [59], which shifts the country into the vulnerable category (based on UN WWDR and UN-Water category thresholds [60]) compared to 2012 data. Under the conditions of high-demand water consumption and a challenging climate, the water-climate-energy-food nexus is being contested by the changing economic interests and political manifestations of natural resource management at the national level. At this juncture, MDP can be observed as a core realm of competing interests over water resources integrating local socio-economic demands at the regional level.

Figure 4. Sectoral Water Demand in Sri Lanka from 1990 to 2025. (Source: The Annual Report-Economic perspective Sri Lanka [39]).

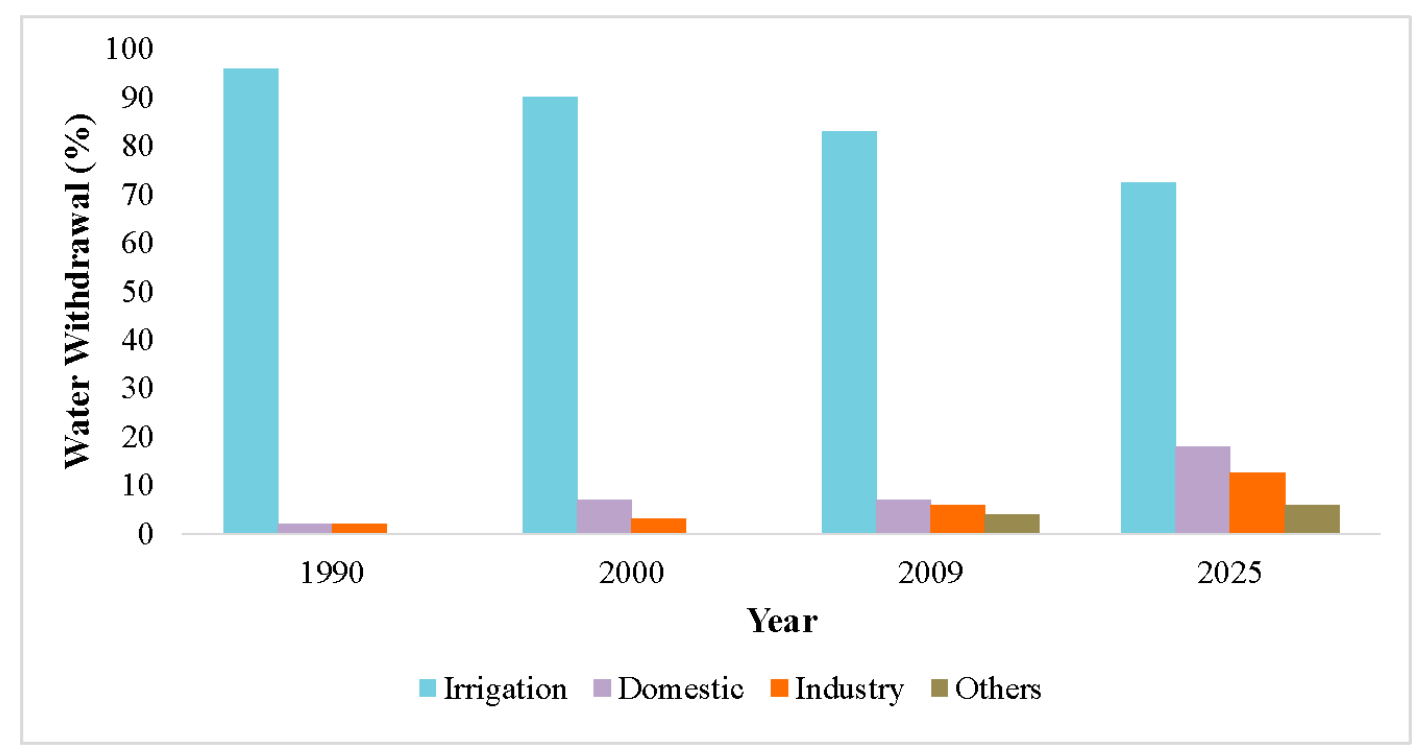

\subsection{Impacts of Seasonal and Temporal Climate Change on Paddy Cultivation}

Temporal and spatial changes in climate conditions and weather systems are crucial factors to take into consideration in the dry zonal water resource management. Releasing water for paddy cultivation depends on the flow regimes of the Mahaweli River and its tributaries. There are two trends reflecting seasonal flow regimes, including the impact of high precipitation and the gradually declining precipitation in catchment areas. As a result of spatial and temporal variations in climate conditions, specifically declining precipitation, rising air and soil temperature, and increasing evaporation rates in 
the irrigational management areas of the Mahaweli River Basin, alteration of seasonal-oriented agricultural decisions in the field study areas could be observed.

There are two main seasons of paddy cultivation in the dry zone, maha (October to February/March) and yala (March/April to July/August) which are defined on the basis of periodic precipitation. Based on the field data, the average precipitation in the maha season could be ranged $750 \mathrm{~mm}$ to $1000 \mathrm{~mm}$, and average precipitation in the yala season could be around $500 \mathrm{~mm}$ or less. In the dry zone, the maha season is the main harvesting season. Some farmers cultivate other crops (grains or vegetables) during the yala and maha seasons, called intermediate cultivation. However, the decision to cultivate an intermediate season depends on water availability. Though agriculture in the dry zone is mainly based on irrigated water, some farmers are accustomed to using rain-fed water in the maha season and irrigated water in the yala season based on seasonal variation of precipitation. Water allocation and distribution for paddy cultivation under the MDP also operate based on this general assumption. However, this seasonal-oriented paddy cultivation is challenged by the impacts of long-term climate change and uncertainty in weather systems. Eriyagama et al. [37] estimate that the water requirement for paddy cultivation in the maha season would be $13 \%-23 \%$ in 2050, as compared to the period from 1961-1990 with reference to quantity and spatial distribution of precipitation and changes in mean temperature.

Figure 5. Losses to agricultural crops in hectares due to droughts and floods, 1974-2007. (Source: Sri Lanka National Report on Disaster Risk, Poverty, and Human Development Relationship, the Disaster Management Centre (DMC) of Sri Lanka [49]).

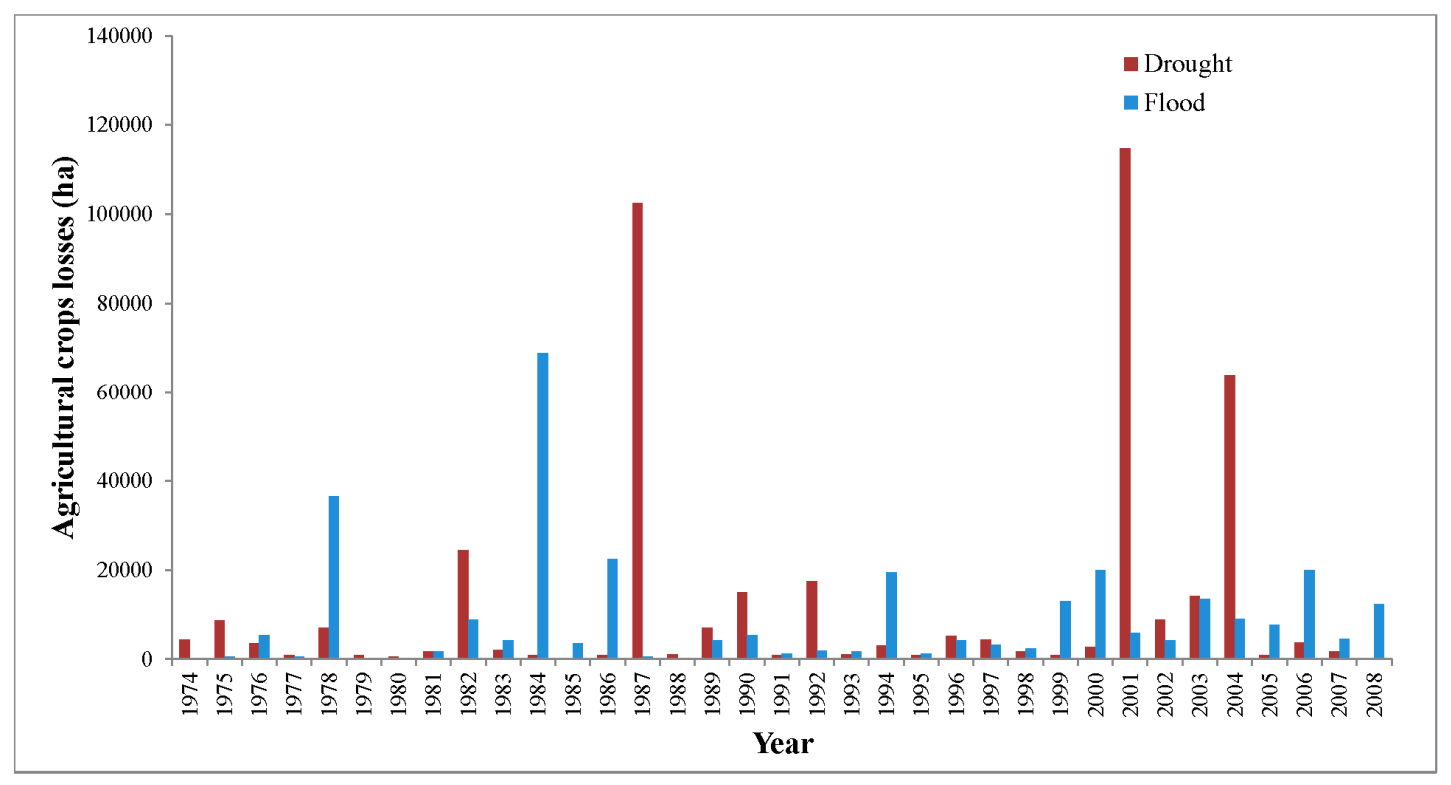

The frequent occurrence of dry weather conditions in recent years has resulted in declining overall agricultural output in downstream areas [61-63]. Particularly, paddy cultivation in the dry zonal area exposes it to short-term and extended severe drought conditions. Paddy yields at early stages of the agronomic period have been affected due to short-term droughts. Furthermore, the lack of water distribution in the reproductive phase of rice could reduce the harvest of paddy. Because of that, farmers are unable to achieve off-season harvesting and intermediate cultivation due to declining rainfall in the yala season. According to data from the Disaster Management Centre of Sri Lanka (DMC) [49], severe drought conditions brought about damage to agricultural land, particularly in the dry zone area. In the 
period from 2001 to 2004, the dry zone area was exposed to extended drought conditions in both the yala and maha periods. In the range of the research area, Hambanthota and Kurunegala are the other districts that were affected by these drought conditions. Figure 5 illustrates the losses of agricultural crops in hectares caused by droughts within the period of 1974 to 2007 [49]. The size of fields under paddy cultivation has been reduced to 66,194 hectares in the dry and intermediate zones of the Mahaweli River Basin as a result of severe drought conditions in the yala season in 2012 [48]. Based on the field data, the dry zone is again prone to be exposed to extended drought conditions from maha season in 2013 to yala season in 2014. These drought conditions impact paddy cultivation as well as the cultivation of other crops. The exact losses to agriculture caused by drought conditions have not yet been officially calculated. Based on the Sri Lanka Disaster Management Center's data from 1974 to 2008 on the frequency and scale of disasters, the Sri Lankan Ministry of Environment analyzes the spatial distribution of extended drought conditions that create vulnerability in the irrigation sector [5] (Figure 6). Based on this GIS-based analysis at the divisional secretariat (DS) level, the high level of vulnerability in the irrigation sector can be scrutinized in the Mahaweli D2, H, I/H, M/H, I, J, L, and M regions.

The interview data explains that paddy cultivation especially in the yala season was either abandoned or earned a limited harvest throughout the last 10-year period. According to the farmers' experiences, there is latent competition over water allocation during periods of limited water availability. According to the authorities of the MDP, water supply for paddy cultivation is frequently controlled and limited due to the inadequate water availability in water tanks and tributaries that are located in the Mahaweli River basin [64]. In interviews, paddy farmers repeatedly expressed deep concern over the lack of adequate water resources, especially during the yala season. The latest data demonstrate that in the yala season of 2014, about 35,000 acres in the Polonnaruwa District (MDP regions) could not be cultivated because of drought conditions [64].

Most of Mahaweli irrigation regions are affected by drought, and the situation has a reciprocal influence on current water resource management practices. The recent drought conditions are extending to Mahaweli B, C, H, and G regions including the Polonnaruwa, Girandurukotte, Galewela, Dambulla, Dehiattakandiya, Anuradhapura, Elahera, Tambuettegama, and Kandalama divisional secretariats (DS) [64]. At the field level, the spatial expansion of dry zonal conditions could be observed towards the intermediate climate zone, which points to the vulnerability of farmers in Kurunegala and Matale districts. Figure 7 demonstrates the impact of drought conditions on paddy cultivation at the divisional secretariat level [5]. According to this GIS-based explanation, a high level of vulnerability in the paddy sector can be observed in the Mahaweli H, I/H, M/H, I, and J regions, as well as the Horrowpothana divisional secretariat. Farmers reveal that they have encountered extensive losses of their paddy harvest over the last 10 years due to increased air temperature and extended drought periods in the maha and yala harvesting periods. Consequently, these effects induce an increase in surface temperature [33,65], which causes deterioration of harvest in paddy cultivation [66]. According to Matthews et al. [67], the increase of seasonal average temperature reduces the paddy harvest. Welch et al. [68] state that a higher minimum temperature decreases the paddy yield, while a higher maximum temperature could increase paddy cultivation. The evaporation of water from rivers and water tanks, diminishing soil moisture, and declining groundwater recharge affect paddy cultivation under the drought conditions [5]. 
Figure 6. Irrigation sector vulnerability to drought exposure.

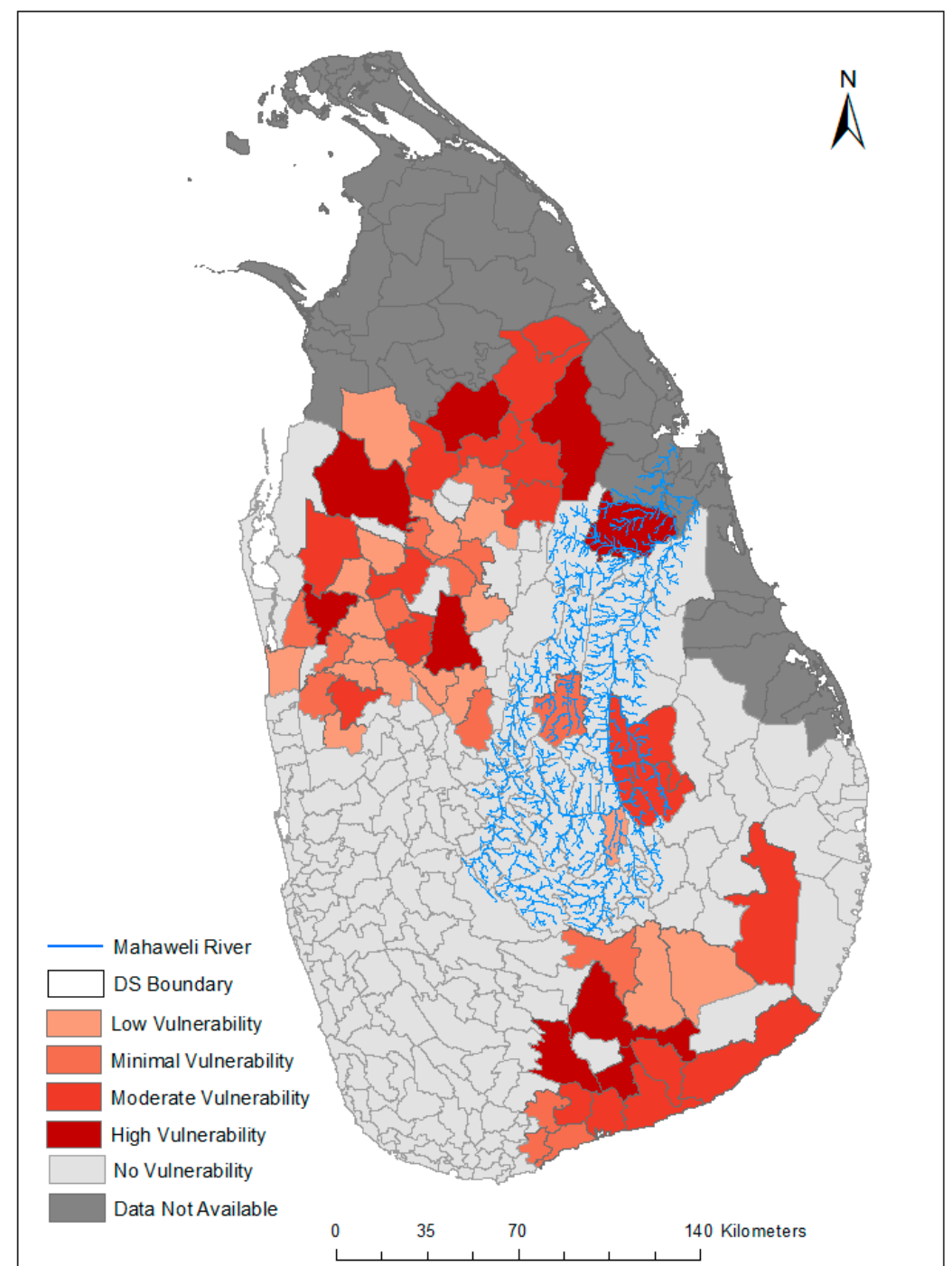

DS: Divisional Secretariat. (Map is re-illustrated based on the data from the Climate Change Vulnerability Data Book [5].)

Constant stream flow cannot be expected throughout the year in the Mahaweli River. Heavy rainfall in the upper catchments, activation of inter-monsoon rainfall in the dry zone area, and cyclone condition activation in the Bay of Bengal generate high stream flow in the river, tributaries, and water channels. These temporal changes in climate conditions and weather systems impact the seasonal orientation of paddy cultivation. Observation demonstrates that farmers are highly vulnerable to unexpected flooding in the yala and maha seasons. Their anxiety over crop protection from flooding of the farm fields is a major issue in agriculture. For example, the activation of the Northeast monsoon in the month of December 2010 severely damaged small, medium, and even large-scale irrigation projects. The DMC data [49] shows considerable damage to agricultural lands because of flood conditions from 1974 to 2008. In the dry zonal area, the Polonnaruwa, Batticaloa, Killinochchi, and Ampara districts encountered severe flood conditions over the last 34 years. As illustrated in Figure 5, substantial losses to agricultural lands (paddy and other crops) were documented in 1978, 1984, 1986, and the period from 1999 to 2008. Around 303,957 hectares of paddy were critically damaged due to drought conditions between 1974 and 2007 [69]. As the Central Bank report of Sri Lanka [63] states, the canal network and 67,900 hectares 
of agricultural land were submerged and 6285 hectares were destroyed. Most of these irrigated projects and agricultural lands are located in the A, B, and D irrigation regions of the MDP [63]. Due to the uncertainty in weather conditions and climate change scenarios, the seasonal dynamics of flow regimes have to be considered with regards to water productivity in agriculture. Seasonal dynamics of river flow regimes should be carefully assessed and studied, because variation of water quantity in rivers and tributaries impacts hydropower generation, irrigation, flood risk management, and water allocation, which are all components of a holistic river basin-oriented water management plan.

Figure 7. Paddy sector vulnerability to drought exposure.

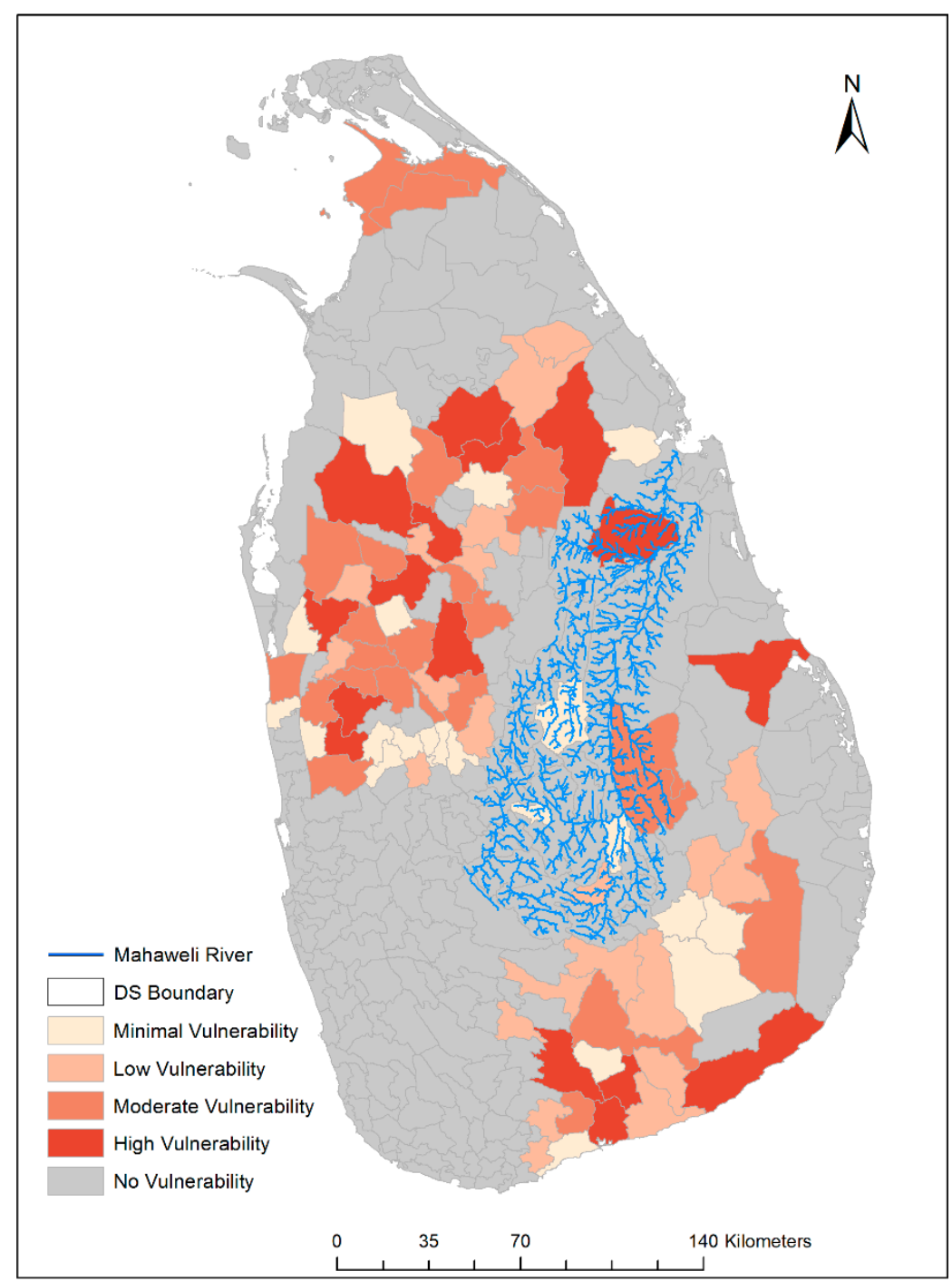

DS: Divisional Secretariat. (Map is re-illustrated based on the data from the Climate Change Vulnerability Data Book [5].)

Drought and floods cause depleted yields or harvest failure, which leads to socioeconomic hardship for small-scale farmers. As recorded from 1974 to 2007 (Figure 8), major hazards that adversely affected paddy cultivation are drought conditions (around 50.83\%) and flood conditions (around 45.83\%). In total, 578,014 hectares under paddy cultivation have been severely damaged due to flood and drought in the 1974-2007 period [69]. Farmers were concerned not only about limited water availability, but also about local, small-scale irrigation technologies, which are in a state of disrepair. With regards to the role 
of MDP authorities and other state agencies, farmers complained about the irrigation bureaucracy's failure to adequately meet their preferences in water allocation, and its lack of attention on maintenance and operation of water supply systems. Therefore, spatial and temporal impacts of climate change and climate variability with drought and flood conditions could reshuffle or alter seasonal decisions on agricultural practices.

Figure 8. Effect of hazards on paddy cultivation, 1974-2007.

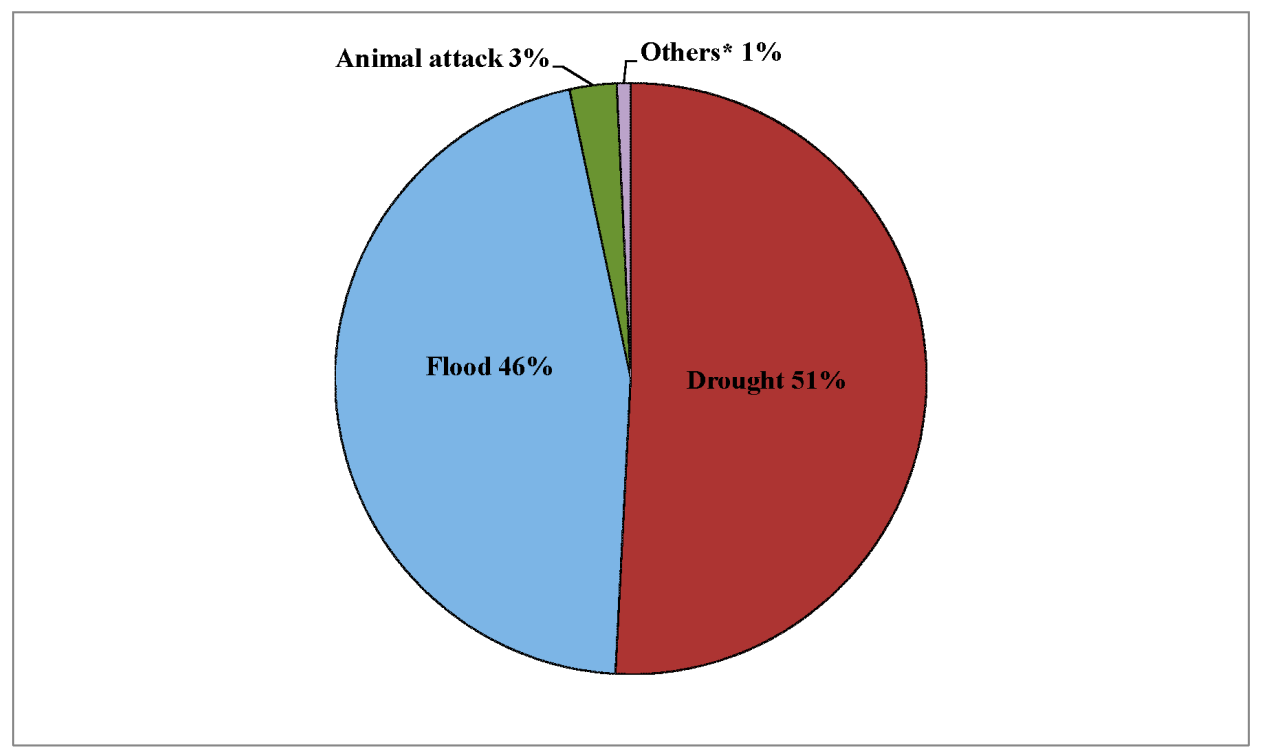

* Others: cyclone, gale, landslide, plague, frost, tsunami, forest fire, and storm (Source: Sri Lanka Disaster Knowledge Network [69]).

\subsection{Modern and Traditional Application in Irrigational Water Management}

Historical evidence demonstrates that water resources and riparian areas of the Mahaweli River had been used for water diversion through canalling and construction of the cascade system for agriculture and domestic consumption [70-72]. The traditional irrigation system, which was based on the strong hydraulic civilization of about 2000 years ago (around 250 B.C. to around 1100 A.D.) in the dry zonal area, is considered an appropriate system for dealing with harsh, changing climate conditions and has the capacity of adapting to long-term changes in climate [72,73]. However, a discrepancy between modern application in the MDP and traditional knowledge of irrigational water management has been observed.

With the development of the agriculture and irrigation sector in the MDP, a considerable number of village tanks (kotu wewa), which were common in the dry zone, were converted into paddy fields. These new paddy fields were distributed among new settlers. The purpose of the village tanks was to supply water for agriculture and other human purposes during extended dry seasons. These small tanks were used when the water level decreased in other, major tanks. The village tank (kotu wewa) system is considered the oldest tank system in Sri Lanka [73]. In ancient times settlements in the dry zone were located around a tank (wewa) rather than along or near a water channel in the dry zone area. The village tanks (kotu wewa) were also an essential unit of the traditional river-basin-oriented complex water management system. The tanks were stored with rainwater or the diverted water from a channel barricaded by small anicut (dams). C. M Madduma Bandara conceptualizes this system as a cascade 
system which is defined as a "connected series of tanks organized within a micro-catchment of the dry zone landscape, storing, conveying and utilizing water from ephemeral rivulets" ([71], p14). A cascade of tanks is constructed by 4 to 10 individual small tanks, with each tank having its own micro-catchment. All village tanks were situated within a single meso-catchment basin that was organized in extent from $15.5 \mathrm{~km}^{2}$ to $25.8 \mathrm{~km}^{2}$, with a model value of $20.7 \mathrm{~km}^{2}$ in the dry zone area. The outflow from a tank was stored by a downstream tank. This water storage could be applied within the command area of the second tank. Thus, the channel runoff was continuously recycled and refilled. This system could assist to surmount the problems of irregularly distributed rainfall, non-availability of large catchment areas, and the difficulty of large tank construction [73]. Local people and archeologists assume that these village-based small tanks have been constructed based on long-term experience of climate conditions and changes in the dry zone area. However, few village tanks (kotu wewa) are still operated for water allocation and distribution in paddy cultivation and other human purposes at the village level in the dry zone area.

Some of the old water channel systems were also reconstructed in concrete under the MDP. In the Eppawal division, Yoda Ela (a water diversion channel), which flowed by nurturing the ecosystem and recharging the groundwater, is reconstructed with concrete as Nawa Jaya Ganga. However, the expected goals from this reconstruction cannot be achieved because the water channels are inundated in the inter-monsoon period [74]. A considerable portion of the paddy harvest is destroyed every year due to unexpected flooding conditions in the Eppawala division. Mishandling or ignorance of traditional technology in water distribution also leads to diminishing soil moisture and impacts on the paddy fields and water springs as a result of lack of recharge of groundwater.

The complex irrigational management system in the MDP weakens voluntary engagement of farmers in water resource management (Figure 9). This complexity leads to the strengthening of bureaucrats in irrigation and agricultural management [75-77]. Due to this hydrocracy [78] in water resource management in the MDP, societal demands and ecological changes are disregarded under bureaucratic control of the technical infrastructure. The highly centralized administrative and management system in the MDP hinders voluntary farmer involvement [76,77,79]. Water allocation and distribution is mainly administered by the officers in the regional office of the Mahaweli Authority in each irrigation region. The research data demonstrate that the "kanna rasweema" (the meeting at the cultivation period) in most regions in the Kantale and Horrowpothana divisions do not empower farmers' voluntary decision-making. At the village level, "kanna rasweema" is a participatory body of farmers competent in decision-making regarding water allocation and distribution. Though farmer associations are responsible for the operation and maintenance of small and minor irrigation schemes, officers in the regional office of the Mahaweli Authority supervise and operate water management. The miscommunication or ignorance of farmers' water demands is the main reason for the loss of expected profit from paddy cultivation prior to other factors, such as pricing issues or lack of storage.

The lack of participation of the farmer associations in water allocation and distribution currently leads to the malfunction of the irrigation canal system at the micro level. The spatial changes in the dry zone are not identified in order to reorganize the water allocation system. The farmers' experience and traditional knowledge are rarely acknowledged or taken into consideration within the water resource management planning of the MDP. Within the technocratic irrigational system of the MDP, farmers are either discouraged or prevented from accessing traditional applications in water resource management 
such as diya bäduma. The term diya bäduma refers to the gradual water allocation system from main water flow (the river) by barricading small anicut (dams). The diverted water flows into the small canal, then into a water channel in a farm field. In the diya bäduma system, the direct engagement of villagers is a crucial factor because the amount of water diversion, time period, and area of spreading water are decided upon the voluntary participation and will of the people. Traditional irrigational practices are considered as part of the traditional body of knowledge adapted to changing climate conditions, ecosystem, and social demands. Lack of opportunities for voluntary engagement in water resource management, especially canal management and water allocation and distribution, contribute to the malfunction of the irrigation canal system at the micro level.

Figure 9. River basin-oriented management system and political-administrative management system in the Mahaweli River Basin area (authors' analysis).

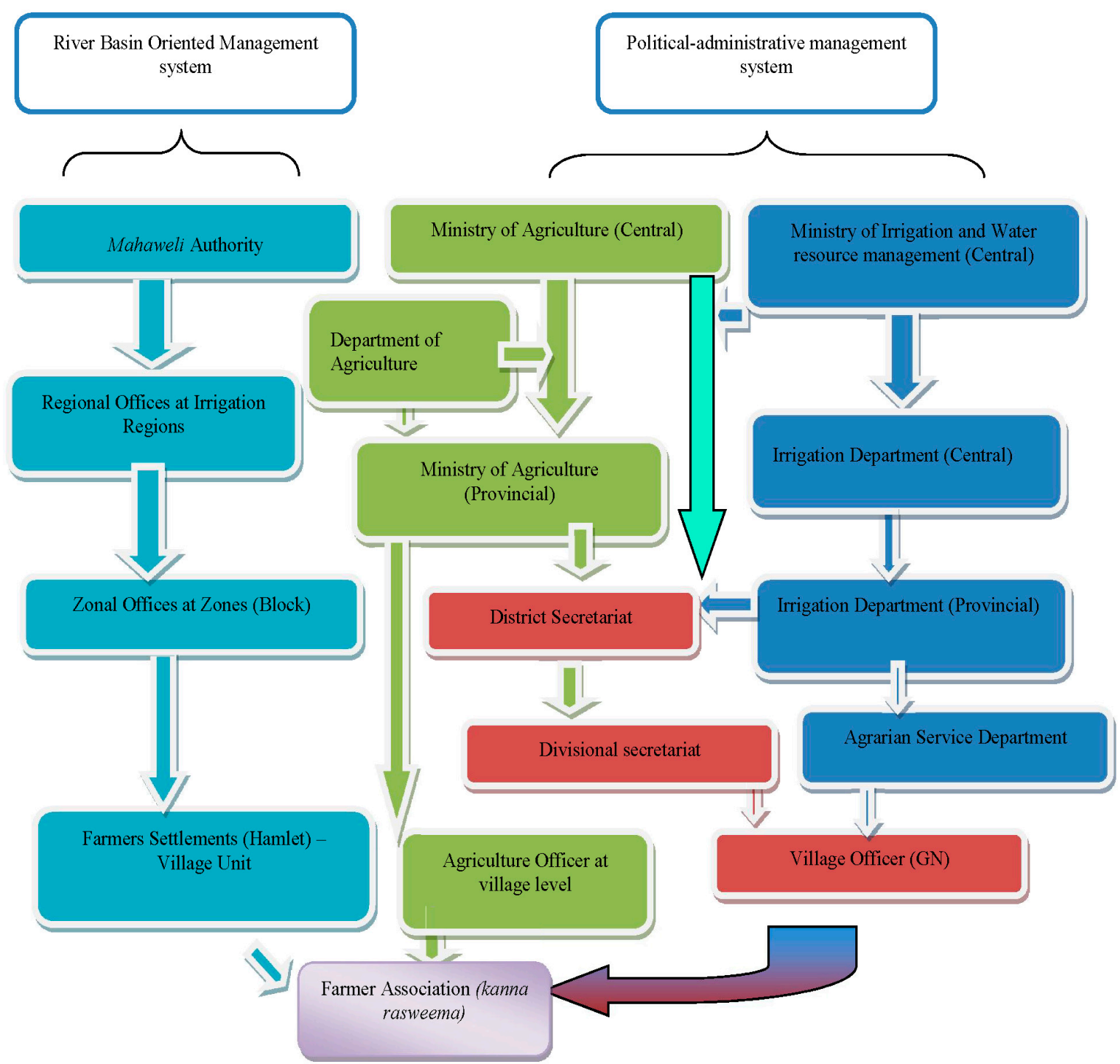

(Arrows indicate the flow of responsibilities and administrative power) 


\section{Conclusions}

A close observation of cross-scale dynamics and effects in water resource management is crucial to taking a sustainable path to empowering rural agricultural systems. In the context of the water-food-climate-energy nexus, small-scale agriculture faces serious challenges not only from climate change and uncertainties in weather conditions, but also from socioeconomic and administrative factors. Paddy cultivation is the main source of income and the basis of food security in small-scale farming in Sri Lanka. A lack of understanding with regards to the spatial and temporal dynamics in climate, socioeconomic demand, and administrative or management functionalities could generate negative consequences for farmers in the dry zone of Sri Lanka. The challenges mentioned above should be addressed by shifting water governance policies. The existing hydrocracy in the MDP should prioritize inclusive and integrated water resource management in order to democratize the water allocation and distribution process in the irrigation sector. Furthermore, research demonstrates that water allocation and distribution in the MDP, taking into consideration competing stakeholders' interests, depend on the effects and dynamics of spatial and temporal climate change and uncertainty in weather conditions. Spatial changes in the dry zone area, taking into account the impacts of climate change, call for a substantial alteration of adaptation policies in water resource management in the MDP. Temporal changes in the climate system and seasonal-oriented agricultural decisions are affected by extended and short-term droughts and flood conditions in the dry zone area. As the main negative consequence, deteriorating paddy harvests translate into socioeconomic hardships that create vulnerability for local paddy farmers. Moreover, the MDP has to acknowledge traditional knowledge in climate and irrigation water management and ancient technological applications in the dry zone area, which has strong roots in historical hydraulic civilization. Therefore, close and in-depth consideration of spatial and temporal changes in climate systems and paddy farmers' socioeconomic demands as altered by seasonal changes are important factors. As the key findings of this research study, these factors should be considered in the future modification of water allocation and application of distribution technologies and in decision-making with regards to water resource management in dry zonal paddy cultivation in Sri Lanka.

\section{Acknowledgments}

This research was facilitated by the Department of Organic Food Quality and Food Culture at the University of Kassel, Germany and the Department of Archeology and Heritage Management at Rajarata University, Sri Lanka. Also, the DAAD-financed EXCEED program on sustainable water management coordinated by TU Braunschweig, Germany partly funded field research in May 2013. The authors gratefully acknowledge D.M.S.L.B Dissanayake and Thilanka Siriwardhana at Rajarata University, Sri Lanka for their enormous support in the field study and illustrations. Our special gratitude goes to Damien Frettsome, Amanda W. Schimunek, and Garret Field for language editing. Also, we would like to thank J. Herden, S. Sapkota, M.T Semiromi, Y. Fasihi, and Pavithra Tantrigoda for their extensive support in this research. We extend our gratitude to all interviewees in the field who dedicated their time and allowed us to participate in their meetings. Without their unconditional contributions, it would have been impossible to complete this field research study. We highly appreciate the opportunity to present our research study at the International Food System Symposium in October 2013, organized by Yale 
University, and critical comments from the audience. Last but not least, we would like to thank the anonymous reviewers of the Journal Climate for their critical and constructive comments.

\section{Author Contributions}

All authors contributed equally to this research work.

\section{Conflicts of Interest}

The authors declare no conflict of interest.

\section{References}

1. Pahl-Wostl, C. The implications of complexity for integrated resources management. Environ. Modell. Softw. 2007, 22, 561-569.

2. Lebel, L. The politics of scale in environmental assessment. In Bridging Scales and Knowledge Systems: Concepts and Applications in Ecosystem Assessment; Reid, W.V., Berkes, F., Wilbanks, T.J., Capistrano, D., Eds.; Island Press: New York, NY, USA, 2006; pp. 37-57.

3. Loucks, D.P.; van Beek, E.; Stedinger, J.R.; Dijkman, J.P.M.; Villars, M.T. Water resources planning and management: An overview. In Water Resources System Planning and Management: An Introduction to Methods, Models and Applications; UNESCO: Paris, France, 2005; pp. 3-36.

4. Termeer, C.J.A.M.; Dewulf, A.; Van Lieshout, M. Disentangling scale approaches in governance research: Comparing monocentric, multilevel, and adaptive governance. Ecol. Soc. 2010, 15, 29.

5. Ministry of Environment-Sri Lanka. Climate Change Vulnerability Data Book; Ministry of Environment: Colombo, Sri Lanka, 2011.

6. Moldenhauer, K.; Slaton, N. Rice growth and development. In Rice Production Handbook; Slaton, N.A., Ford, L.B., Bernhardt, J.L., Cartwright, R.D., Gardisser, D., Gibbons, J., Huitink, G., Koen, B., Lee, F.N., Miller, D.M. et al, Eds. Cooperative Extension Service, Division of Agriculture, University of Kansas: Lawrence, KS, USA, 2004; pp. 7-14.

7. Elakanda, S. Resource-based development: Experience from Mahaweli. In CRBOM Small Publications Series No. 29; Centre for River Basin Organizations and Management: Central Java, Indonesia, 2010; pp. 1-9.

8. Warner, J.; Wester, P.; Bolding, A. Going with the flow: River basins as the natural units for water management? Water Policy 2008, 10, 121-138.

9. Gibson, C.C.; Ostrom, E.; Ahn, T.K. The concept of scale and the human dimensions of global change: A survey. Ecol. Econ. 2000, 32, 217-239.

10. Cash, D.W.; Adger, W.F.; Berkes, P.; Garden, L.; Lebel, P.; Olsson, L.; Pritchard, O.Y. Scale and cross-scale dynamics: Governance and information in a multilevel world. Ecol. Soc. 2006, 11, 8.

11. Pahl-Wostl, C. Transitions towards adaptive management of water facing climate and global change. Water Recour. Manag. 2007, 21, 49-62.

12. Kok, K.; Veldkamp, T. Scale and governance: Conceptual considerations and practical implications. Ecol. Soc. 2011, 16, 29-45.

13. Adger, W.N.; Arnell, N.W.; Tompkins, E.L. Successful adaptation to climate change across scales. Glob. Environ. Change 2005, 15, 77-86. 
14. WWAP (World Water Assessment Programme). The United Nations World Water Development Report 4: Managing Water under Uncertainty and Risk; UNESCO: Paris, France, 2012.

15. Molle, F.; Wester, P.; Hirsch, P.; Jensen, J.R.; Murray-Rust, H.; Paranjpye, V.; Pollard, S.; Van der Zaag, P. River basin development and management. In Water for Food and Water for Life; Molden, D., Ed.; International Water Management Institute (IWMI): Colombo, Sri Lanka, 2007; pp. 585-624.

16. Van Lieshout, M.; Dewulf, A.; Aarts, N.; Termeer, C. Do scale frames matter? Scale frame mismatches in the decision making process about a "mega farm" in a small Dutch village. Ecol. Soc. 2011, 16, 38-53.

17. Leibold, M.A.; Holyoak, M.; Mouquet, N.; Amarasekare, P.; Chase, J.M.; Hoopes, M.F.; Gonzalez, A. The metacommunity concept: A framework for multi-scale community ecology. Ecol. Lett. 2004, 7, 601-613.

18. Swyngedouw, E. Place, Nature and the Question of Scale: Interrogating the Production of Nature; Discussion Paper 5; Brandenburgische Akademie der Wissenschaften: Berlin, Germany, 2010; pp. 5-29.

19. Swyngedouw, E. The political economy and political ecology of the hydro-social cycle. J. Contemp. Water Res. Educ. 2009, 142, 56-60.

20. Lebel, L.; Garden, P.; Imamura, M. The politics of scale, position, and place in the governance of water resources in the Mekong region. Ecol. Soc. 2005, 10, 32-58.

21. Dore, J.; Lebel, L. Deliberation and scale in Mekong Region water governance. Environ. Manag. 2010, 46, 60-80.

22. Moss, T.; Newig, J. Multilevel water governance and problems of scale: Setting the stage for a broader debate. Environ. Manag. 2010, 46, doi:10.1007/s00267-010-9531-1.

23. Withanachchi, S.S.; Houdret, A.; Nergui, S.; Gonzalez, E.E.I.; Tsogtbayar, A.; Ploeger, A. (Re)Configuration of Water Resources Management in Mongolia: A Critical Geopolitical Analysis; International Center for Development and Decent Work (ICDD): Kassel, Germany, 2014.

24. De Silva, C.S.; Weatherhead, E.K.; Knox, J.W.; Rodriguez-Diaz, J.A. Predicting the impacts of climate change-A case study of paddy irrigation water requirements in Sri Lanka. Agric. Water Manag. 2007, 93, 19-29.

25. Jayawardanaa, D.T.; Pitawalab, H. M. T. G. A.; Ishigaa, H. Groundwater quality in different climatic zones of Sri Lanka: Focus on the occurrence of fluoride. Int. J. Environ. Sci. Dev. 2010, 1, 244-250.

26. Creswell, J.W.; Clark, V.L.P. Designing and Conducting Mixed Methods Research; Sage Publication: London, UK, 2007.

27. Hesse-Biber, S.N. Mixed Methods Research: Merging Theory with Practice; Guilford Press: London, UK, 2010.

28. Thompson, P. Voice of the Past: Oral History; Oxford University Press: Oxford, UK. 2000.

29. Conway, D. Managing water in the Ruaha River Basin: The role of climate variability and risk. In Proceedings of the 2005 East African Integrated River Basin Management Conference, Morogoro, Tanzania, 7-9 March 2005; pp. 420-427. 
30. Keskinen M.; Chinvanno, S.; Kummu, M.; Nuorteva, P.; Snidvongs, A.; Varis, O.; Västilä, K. Climate change and water resources in the Lower Mekong River Basin: Putting adaptation into the context. J. Water Clim. Change 2010, 1, 103-117.

31. Lovell, C.; Mandondo, A.; Moriarty, P. The question of scale in integrated natural resource management. In Integrated Natural Resource Management. Linking Productivity, the Environment and Development; Campbell, B.M., Sayer, J., Eds.; CABI: Wallingford, UK, 2003; pp. 109-136.

32. Domroes, M.; Schaefer D. Trends of recent temperature and rainfall changes in Sri Lanka. In Proceedings of 2000 International Conference on Climate Change and Variability, Tokyo, Japan, 13-17 September 2000; pp. 197-204.

33. Zubair, L.; Siriwardhana, M.; Chandimala, J.; Yahiya, Z. Predictability of Sri Lankan rainfall based on ENSO. Int. J. Climatol. 2008, 28, 91-101.

34. Manawadu, L.; Fernando, N. Climate Changes in Sri Lanka; Department of Meteorology, Sri Lanka: Colombo, Sri Lanka, 2008.

35. Muththuwatta, L.P.; Liyanage, P.K.N.C. Climate Change Models Shift Boundaries of Agro-Ecological Zones in Sri Lanka. Available online: http:/climatenet.blogspot.de/2013/09/ climate-change-models-shift-boundaries.html (accessed on 10 July 2014).

36. Shantha, W.W.A.; Jayasundara, J.M.S.B. Study on changes of rainfall in the Mahaweli Upper Watershed in Sri Lanka due to climatic changes and develop a correction model for global warming. In Proceedings of the 2005 International Symposium on the Stabilisation of Greenhouse Gas Concentrations, Exeter, UK, 1-3 February 2005.

37. Eriyagama, N.; Smakhtin, V.; Chandrapala, L.; Fernando, K. Impacts of Climate Change on Water Resources and Agriculture in Sri Lanka: A Review and Preliminary Vulnerability Mapping; IWMI Research Report 135; International Water Management Institute: Colombo, Sri Lanka, 2010.

38. Cruz, R.V.; Harasawa, H.; Lal, M.; Wu, S.; Anokhin, Y.; Punsalmaa, B.; Honda, Y.; Jafari, M.; Li, C.; Huu Ninh, N. Asia. In Climate Change 2007: Impacts, Adaptation and Vulnerability; Parry, M.L., Canziani, O.F., Palutikof, J.P., Van der Linden, P.J., Hanson, C.E., Eds.; Cambridge University Press: Cambridge, UK, 2007; pp. 469-506.

39. Ministry of Finance and Planning, Sri Lanka. Economic Perspective: Sri Lanka. In Annual Report 2012; Ministry of Finance and Planning, Sri Lanka: Colombo, Sri Lanka, 2012; pp. 19-48.

40. IPCC. Summary for policymakers. In Climate Change 2014: Impacts, Adaptation, and Vulnerability. Part A: Global and Sectoral Aspects. Contribution of Working Group II to the Fifth Assessment Report of the Intergovernmental Panel on Climate Change; Field, C.B., Barros, V.R., Dokken, D.J., Mach, K.J., Mastrandrea, M.D., Bilir, T.E., Chatterjee, M., Ebi, K.L., Estrada, Y.O., Genova, R.C., et al., Eds.; Cambridge University Press: Cambridge, UK, 2014; pp. 1-32.

41. Jayawardene H.K.W.I.; Sonnadara, D.U.J.; Jayewardene, D.R. Trends of rainfall in Sri Lanka over the last century. Sri Lankan J. Phys. 2005, 6, 7-17.

42. Zubair L. ENSO influences on Mahaweli Stream flow in Sri Lanka. Int. J. Climatol. 2003, 23, 91-102.

43. Dharmaratne, G.H.P. Impact of changing weather patterns. Vidurava 2005, 22, 9-13.

44. Riedlinger, D.; Berkes, F. Contributions of traditional knowledge to understanding climate change in the Canadian Arctic. Polar Record 2001, 37, 315-328. 
45. Nyong, A.; Adesina, F.; Elasha, B.O. The value of indigenous knowledge in climate change mitigation and adaptation strategies in the African Sahel. Mitig. Adapt. Strat. Glob. Change 2007, 12, 787-797.

46. David, W.; Ploeger, A. Indigenous Knowledge (IK) of water resources management in West Sumatra, Indonesia. Fut. Food: J. Food Agric. Soc. 2014, 2, 52-60.

47. Byg, A.; Salick, J. Local perspectives on a global phenomenon-Climate change in Eastern Tibetan villages. Glob. Environ. Change 2009, 19, 156-166.

48. Mahaweli Authority. Performance-2012 and Investment Plan-2013, Performance Report up to August-2012; Planning and Monitoring Unit in Mahaweli Authority: Colombo, Sri Lanka, 2012.

49. The Disaster Management Centre (DMC) of the Ministry of Disaster Management. Sri Lanka National Report on Disaster Risk, Poverty and Human Development Relationship; The Disaster Management Centre (DMC) of the Ministry of Disaster Management: Colombo, Sri Lanka, 2014.

50. Mahaweli Authority. Mahaweli Hand Book (Statistical Hand Book) 2011-2012; Planning and Monitoring Unit in Mahaweli Authority: Colombo, Sri Lanka, 2012.

51. Parliament of Sri Lanka. Mahaweli Authority Parliament-Act No. 23 of 1979; Parliament of Sri Lanka: Sri Jayawardenapura, Sri Lanka, 1979.

52. Hettige, S.T. Socioeconomic issues relating to sustainability of the mahaweli upper catchment Sri Lankan. J. Soc. Sci. 1997, 20, 43-62.

53. Lakshman, W.D.; Tisdell, C.A. Introduction to Sri Lanka's development since independence. In Sri Lanka's Development Since Independence: Socio-Economic Perspectives and Analyses; Nova Science Publishers Inc.: New York, NY, USA, 2000; pp. 1-22.

54. Haturusinha, R.L.; Theivasagayam, K.; Perera, D.T.D. Water and sanitation for Mahaweli. In Proceedings of the 1994 WEDC Conference, Colombo, Sri Lanka, 22-26 August 1994; pp. 242-245.

55. Wettasinha, C. Scaling up participatory development in agricultural settlements. Leisa. Mag. 2001, $39-42$.

56. Perera, G.D.; Sennema, B. Towards sustainable development in Mahaweli Settlements through farmer participation. In Participatory Technology Development Working Paper 6; Diop, J.-M., Waters-Bayer, A., Eds.; Ecoculture Netherlands and Mahaweli Authority: Colombo, Sri Lanka, 2002; pp. 1-23.

57. Hewawasam, T. Effect of land use in the upper Mahaweli catchment area on erosion, landslides and siltation in hydropower reservoirs of Sri Lanka. J. Nat. Sci. Found. Sri Lanka 2010, 38, 3-14.

58. Lezama Escalante, C. A Cultural approach to water management policies. In Five Years of EXCEED. Sustainable Water Management in Developing Countries; Bahadir, M., Haarstrick, A., Eds.; Technische Universität Braunschweig: Braunschweig, Germany 2014; pp. 256-265.

59. AQUASTAT. Available online: http://www.fao.org/nr/water/aquastat/main/index.stm. (accessed on 20 October 2014).

60. WWAP (United Nations World Water Assessment Programme). The United Nations World Water Development Report: Water and Energy; UNESCO: Paris, France, 2014.

61. Bastiaassen, W.G.M.; Chandrapala, L. Water balance availability across Sri Lanka for assessing agricultural and environmental water use. Agric. Water Manag. 2003, 58, 171-192.

62. Central Bank of Sri Lanka. Annual Report 2012; Central Bank of Sri Lanka: Colombo, Sri Lanka, 2012. 
63. Central Bank of Sri Lanka. Annual Report 2011; Central Bank of Sri Lanka: Colombo, Sri Lanka, 2011.

64. Wickremasekara, D. Paddy Cultivation Slashed; Rice to be Imported. Available online: http://www.sundaytimes.lk/140406/news/paddy-cultivation-slashed-rice-to-be-imported-91848.html (accessed on 20 July 2014).

65. Malmgren, B.A.; Hulugalla, R.; Hayashi, Y.; Mikami, T. Precipitation trends in Sri Lanka since the 1870s and relationships to El Niño-Southern oscillation. Int. J. Climatol. 2003, 23, 1235-1252.

66. Niranjan, F.; Jayatilaka, W.; Singh, N.P.; Bantilan, M.C.S. Mainstreaming Grassroots Adaptation and Building Climate Resilient Agriculture in Sri Lanka; Policy Brief No. 20; International Crops Research Institute for the Semi-Arid Tropics: Hyderabad, India, 2013.

67. Matthews, R.B.; Kropff, M.J.; Horie, T.; Bachelet, D. Simulating the impact of climate change on rice production in Asia and evaluating options for adaptation. Agric. Syst. 1997, 54, 399-425.

68. Welch, J.R.; Vincent, J.R.; Auffhammer, M.; Moya, P.F.; Dobermann, A.; Dawe, D. Rice yields in tropical/subtropical Asia exhibit large but opposing sensitivities to minimum and maximum temperatures. Proc. Natl. Acad. Sci. USA 2010, 107, 14562-14567.

69. Sri Lanka Disaster Knowledge Network. Disaster Profile of Sri Lanka. Available online: http://www.saarc-sadkn.org/countries/srilanka/disaster_profile.aspx (accessed on 10 October 2014).

70. Geekiyanage, N.; Pushpakumara, D.K.N.G. Ecology of ancient Tank Cascade Systems in island Sri Lanka. J. Mar. Island Cult. 2013, 2, 93-101.

71. Madduma Bandara, C.M. Tank cascade systems in Sri Lanka: Some thoughts on their development implications. In Summaries of Papers Presented at Irrigation Research Management Unit Seminar Series during 1994; Haq, K.A., Wijayaratne, C.M., Samarasekera B.M.S., Eds.; IIMI (International Irrigation Management Institute): Colombo, Sri Lanka, 1995; p. 14.

72. Schütt, B.; Bebermeier, W.; Meister, J.; Withanachchi, C.R. Characterisation of the Rota Wewa tank cascade system in the vicinity of Anuradhapura, Sri Lanka. J. Geogr. Soc. Berl. 2013, 144, 51-68.

73. Withanachchi, C.R. Hydro-technology in dry zone irrigation management of ancient Sri Lanka and its potential benefits for the world the international conference on Traditional Knowledge for Water Resource Management (TKWRM). In Proceedings of the 2012 International Center on Qanats and Historic Hydraulic Structure (ICQHS), Yazd, Iran, 21-23 February 2012; pp. 1-7.

74. Panapitiya, M. "Inconvenient Truth" behind engineering designs of irrigation projects developed during the last century. Econ. Rev. Peopl. Bank Colombo 2010, 36, 16-20.

75. Gunawardena, E.R.N. Operationalizing IWRM Through River Basin Planning and Management. Available online: http://tinyurl.com/ky53p9p (accessed on 5 October 2013).

76. Merrey, D.J. Potential for devolution of management to farmers' organizations in an hierarchical irrigation management agency: The case of the Mahaweli Authority of Sri Lanka. In The Blurring of a Vision-The Mahaweli: Its Social, Economic and Political Implications; Müller, H.P., Hettige, S.T., Eds.; Sarvodaya Publication: Ratmalana, Sri Lanka, 1995; pp. 222-243.

77. Müller, H.P.; Hettige, S.T. Introduction the Mahaweli-The Blurring of a Vision. In The Blurring of a Vision-The Mahaweli: Its Social, Economic and Political Implications; Müller, H.P., Hettige, S.T., Eds.; Sarvodaya Publication: Ratmalana, Sri Lanka, 1995; pp. 1-22. 
78. Mollinga, P.P. The water resources policy process in India: Centralization, polarization and new demands on governance. In Governance of Water: Institutional alternatives and Political Economy; Ballabh, V., Ed.; Sage: New Delhi, India, 2008; pp. 339-370.

79. Wijesekera, N.T.S.; Wickramaarachchi, T.N. Reality of irrigation water use and suggestions for better management: A comparison of two schemes from Sri Lanka. Water Sci. Technol. 2003, 48, 197-206.

(C) 2014 by the authors; licensee MDPI, Basel, Switzerland. This article is an open access article distributed under the terms and conditions of the Creative Commons Attribution license (http://creativecommons.org/licenses/by/4.0/). 